\title{
An improved model for linking phosphorus loads in runoff to climate, soil and agricultural management
}

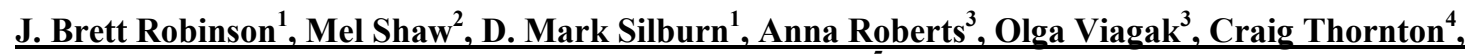 \\ David McClymont ${ }^{5}$
}

\author{
${ }^{1}$ Dept of Environment and Resource Management, PO Box 318, Toowoomba, Queensland 4350 \\ ${ }^{2}$ Dept of Environment and Resource Management, Ecosciences Precinct, Dutton Park, Queensland 4102 \\ ${ }^{3}$ Dept of Department of Primary Industries, RMB 1145 Chiltern Valley Road, Rutherglen Victoria 3685 \\ ${ }^{4}$ Dept of Department of Environment and Resource Management, State Farm Rd, Biloela, Queensland 4175 \\ ${ }^{5}$ DHM Environmental Software Engineering Pty Ltd, dhmsoftware.com.au
}

\section{Email: brett.robinson@derrn.qld.gov.au}

\begin{abstract}
Soil phosphorus (P) is one of the nutrients that contribute to eutrophication of waterways, algal blooms and damage to coral reefs. Reducing P movement from farm paddock to the broader environment often requires comprehensive, catchment-wide approaches to management. The substantial complexity of the physical and managerial causes of $\mathrm{P}$ pollution has led to a role for simulation models in evaluating the efficacy of regulations and management changes.
\end{abstract}

In Queensland, the Reef Plan program (http://www.reefplan.qld.gov.au) addresses issues of sediment, nutrient and pesticide impact on the health and future of the Great Barrier Reef. Some of the associated regulations are concerned with the use of $\mathrm{P}$ fertilizer. The HowLeaky? model is one of few biophysical models that represent agricultural management, biophysical conditions and $\mathrm{P}$ exports. As reported at MODSIM07, information about $\mathrm{P}$ export was added to an existing model of water balance and sediment export (HowLeaky?) to create a useful model of P export from agriculture. However, the predictive power of the model was modest, especially over short periods (e.g. individual days).

To improve the predictive power of the model, several changes have been made, including (i) additional empirical functions for estimating the enrichment of total $\mathrm{P}$ in sediment, and (ii) additional functions for estimating concentration of soluble $\mathrm{P}$ in runoff $(\mathrm{mg} \mathrm{P} / \mathrm{L})$. Soil adsorption of $\mathrm{P}(\mathrm{P}$ buffering), which affects the soluble $\mathrm{P}$ concentration in runoff, is now estimated from the widely available phosphorus buffering index test (PBI) rather than phosphorus buffering capacity $(\mathrm{PBC})$. Large, high-quality datasets are used to evaluate these relationships.

A case study is presented where HowLeaky? has been used to estimate P loads generated at a site in the GBR catchment. The Brigalow Catchment Study is a long-term study of the effects of land clearing and agriculture on the water balance and water quality. It is located in central Queensland, has a subcatchment that is cropped, has representative soils, and is part of the Fitzroy Catchment. HowLeaky? reproduced daily runoff amounts very well, and the revised $\mathrm{P}$ model in HowLeaky? was acceptably accurate at predicting daily $\mathrm{P}$ loads. Modelling predicted the long-term totals (6 years) of soluble and particulate $\mathrm{P}$ export from the field site with less than $50 \%$ error. This is a better-than-expected result with an un-calibrated model, as $\mathrm{P}$ exports are notoriously difficult to predict.

Keywords: Phosphorus, runoff, water quality, management 


\section{INTRODUCTION}

Phosphorus $(\mathrm{P})$, nitrogen $(\mathrm{N})$ and other nutrients and materials are hazardous to aquatic ecosystems. Enrichment of ecosystems with $\mathrm{P}$ is an important precursor to eutrophication - a globally significant problem of rivers, lakes, estuaries, and coastal oceans (Sharpley et al. 1994). Eutrophication is a complex condition associated with blooms of toxic algae, oxygen depletion, loss of seagrass, loss of coral reefs, and changes in food webs. Economic impacts can be substantial, especially on the tourism, fishing and shellfish industries. Although eutrophication can be reversed, rates of recovery are typically slow, so prevention is important.

Nonpoint sources of $\mathrm{P}$ (such as agricultural lands) are more important than point sources (such as treatment works) in Australia and much of the USA. Differences in the generation and management of point and nonpoint P pollution are discussed by Herath (1997) and Sharpley (1995). In general, runoff from farms, suburban and extensive urban areas often carries large amounts of $\mathrm{P}$ into waterways. The contribution from extension grazing enterprises is variable, as erosion and sediment losses may be low, and in these cases soluble P may be the dominant form of P entering waterways (Sharpley et al. 1992). In north-eastern Australia, the Great Barrier Reef (GBR) is thought to be affected by P pollution as well as suspended sediments, $\mathrm{N}$ and pesticides. Land use in the GBR catchments is a complex mix of grazing, grain cropping, sugar cane cropping, horticulture, native forests and urban areas. This complexity is expected to lead to heterogeneous rates, causal factors and forms of contributions of $\mathrm{P}$ to the GBR lagoon.

Recently, the Reef Water Quality Protection Plan (Reef Plan, http://www.reefplan.qld.gov.au) was introduced to lessen the impacts of non-point pollution on the GBR. The Reef Water Quality Protection Plan was launched by the Australian and Queensland Governments in 2003 and updated in 2009, with two primary goals: (i) to halt and reverse the decline in water quality entering the Reef lagoon by 2013 , and (ii) to ensure that by 2020 the quality of water quality entering the Reef lagoon from adjacent catchments has no detrimental impact on the health and resilience of the Great Barrier Reef (http://www.reefplan.qld.gov.au/about/rwqpp.shtm). Assessment is via quantitative targets for land management and water quality outcomes. In particular, the Reef Plan aims to: (i) reduce the pollutant load from non-point sources in the water entering the Reef by encouraging good planning and assist land managers in adopting best management practices (BMPs), and (ii) rehabilitate and conserve areas of the Reef catchment that have a role in removing water borne pollutants. Reef Plan aims that relate to P pollution include: (i) ensuring that inputs of $\mathrm{P}$ and $\mathrm{N}$ fertilizers don't exceed crop requirements, and (ii) reducing tillage in cropping systems to reduce soil erosion and $\mathrm{P}$ loss, and (iii) improving pasture and grazing management so that erosion and $\mathrm{P}$ losses are reduced.

In order to understand the importance of the various contributions of $\mathrm{P}$ from agricultural land use to the GBR lagoon, a range of monitoring and modelling studies are underway. Simulation models provide the opportunity to extend currently available observed data to hypothetical or projected land management scenarios. The Reef Plan project uses the HowLeaky? model (Rattray et al. 2004, Silburn et al. 2007) to simulate the water balance (runoff, transpiration, deep drainage, etc.) of a vast number of combinations of crop growth and land management conditions at the paddock scale in the GBR catchments. The HowLeaky? model has estimated P export for some time (Robinson et al. 2007) the accuracy of the estimates has been variable in testing, so improvements were sought prior to its use in the Reef Plan project. This paper reports improvements to the model, and limited testing in a catchment study within the GBR catchments.

\section{METHODS}

\subsection{The $\mathbf{P}$ model in HowLeaky?}

The original P model in HowLeaky? was described by Robinson et al. (2007). Changes to this model are summarized in Table 1. There are now three alternative methods of estimating dissolved reactive $P$ concentrations (mg/L) in runoff (DRP, a.k.a. filterable reactive P): (i) a suite of three functions, based on large datasets, that predict DRP from the degree of saturation of the P adsorption capacity of the soil, (ii) a Table 1. Methods of estimating P concentrations in runoff in the HowLeaky? model.

\begin{tabular}{|c|c|c|}
\hline & Previous model & Current model \\
\hline $\begin{array}{l}\text { Particulate } \mathrm{P}(\mathrm{PP}, \\
\mathrm{mg} / \mathrm{L})\end{array}$ & $\begin{array}{l}\text { Sediment concentration in } \\
\text { runoff }(\mathrm{mg} / \mathrm{L}) \times \text { Soil } \mathrm{P} \\
(\mathrm{mg} / \mathrm{kg}) \times \text { Enrichment ratio }\end{array}$ & $\begin{array}{l}\text { Similar, but with three options for calculating enrichment: } \\
\text { (ii) a constant, } \\
\text { (ii) a modification of the approach in the CREAMS model, and } \\
\text { (iii) an empirical function based on unpublished data from Queensland. }\end{array}$ \\
\hline
\end{tabular}


function (Eqn 1, below) based on dissolved P (DP, mg/L) runoff data from pastures (Dougherty et al. 2010) and estimating DRP as a proportion of DP (Eqn 2, below), and (iii) a constant proportion of "available" or "plant available" soil phosphorus (ie. $\mathrm{mg} \mathrm{P} / \mathrm{L}: \mathrm{mg} / \mathrm{kg}$ ), as used in the Generalised Watersheds Loading Functions (GWLF) model (Haith and Shoemaker 1987) and others. These coefficients used in method (iii) are typically 0.005 to 0.01 .

$\log (\mathrm{DP})=0.85 \times(-2.45+1.58 \times \log ($ Colwell $)-0.33 \times \log ($ Colwell $) \times \log (\mathrm{PBI}))$

$\mathrm{DRP}=0.8 \times \mathrm{DP}$

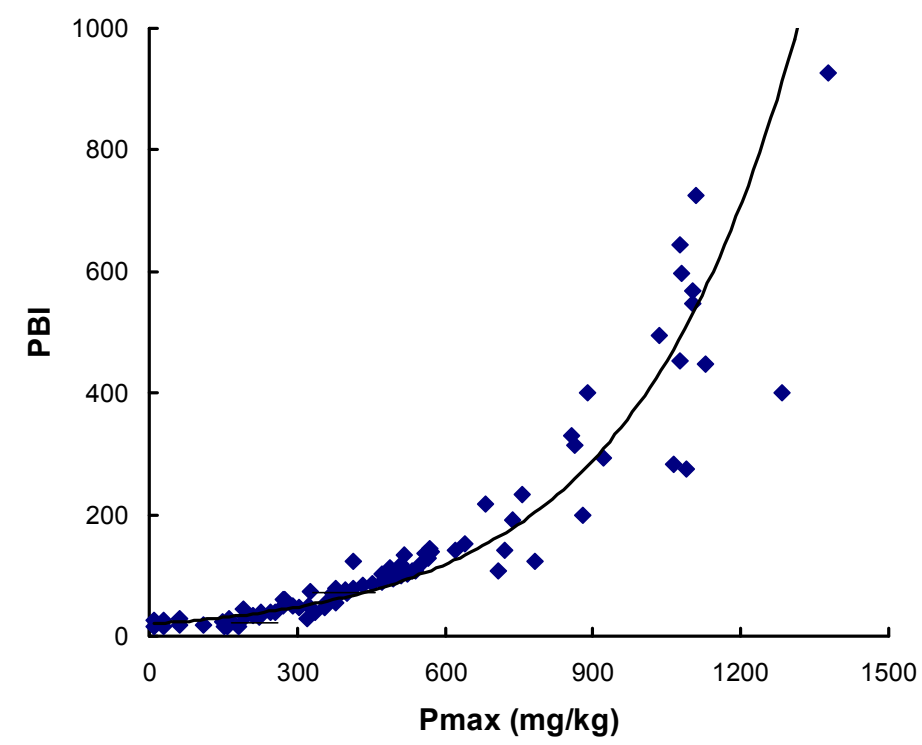

Figure 1. A relationship between Langmuir $P$ sorption capacity (Pmax) and phosphorus buffering index (PBI) for Australian soils. Data from Burkitt (pers. comm.). The line (PBI= 15.1 $\mathrm{e}^{0.0034 . P m a x}$ ) was fitted by linear regression to log-transformed data.

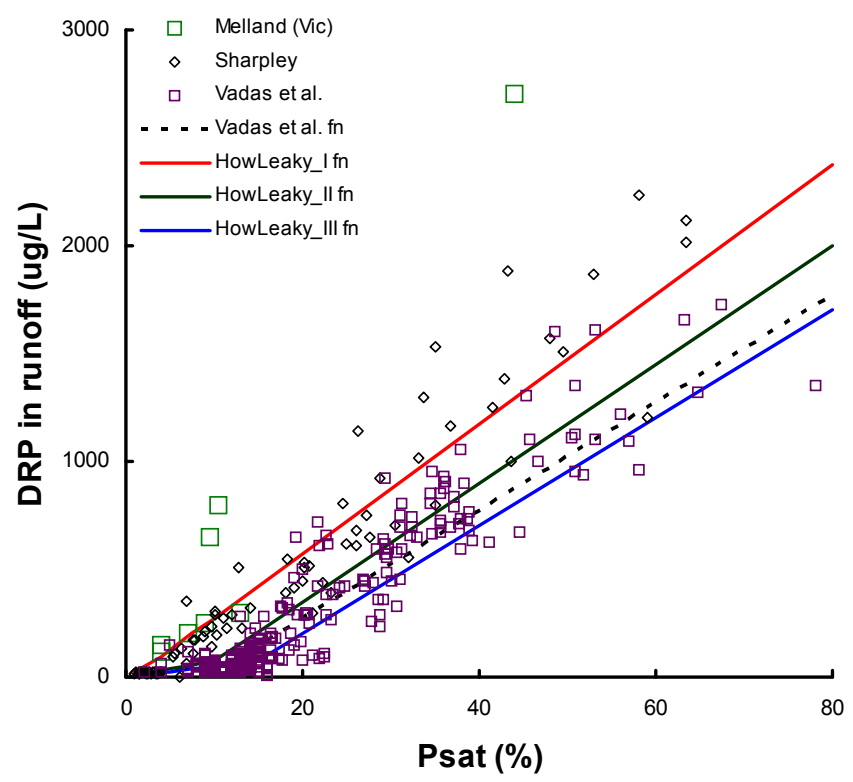

Figure 2. Dissolved reactive $P$ in runoff, reported by Sharpley (1995), Melland, A. (pers. comm.) and Vadas et al. (2005). HowLeaky includes 3 user-selected function (I, II and III). 
P saturation (Psat\%) is available P, as measured by the Colwell method (1963), as a percentage of the soil P sorption capacity (Pmax, $\mathrm{mg} / \mathrm{kg}$ ). P saturation is a simple notion that can be difficult to estimate and employ. Pmax was previously estimated in HowLeaky? from soil phosphorus buffer capacity (PBC), described by Ozanne and Shaw (1968) and the adsorption equation of Langmuir (1916). However, the method is laborious, and consequently, not widely adopted. HowLeaky? now estimates Pmax from PBI - a widely measured, single point measure of $\mathrm{P}$ buffering (Burkitt et al. 2002). Figure 1 shows PBI and Langmuir Pmax for a large set of data from L. Burkitt (pers. comm., for the soils described in Burkitt et al. 2002). The inverse of this equation is used in HowLeaky? to predict Pmax from PBI.

As well as modelling runoff and erosion, HowLeaky? and other models of $\mathrm{P}$ transport need to account for the preferential transport of P-rich fine material from hillslopes (Wolfe 2007). In HowLeaky? there are three alternative methods for calculating the ratio describing the enrichment of soil $\mathrm{P}(\mathrm{mg} / \mathrm{kg})$ into sediment suspended in runoff $(\mathrm{mg} / \mathrm{kg})$ :

(i) a fixed ratio,

(ii) an empirical function based on the clay content (\%) of the topsoil (Equation 4),

enrichment ratio $=$ minimum $(10$, maximum $(1,15-0.33 *$ Clay $\%))$

where Clay $\%$ is the percentage clay in the topsoil. The range of the function is limited to $1(\mathrm{Clay} \%>45)$ to $10($ Clay\% < 15).

(iii) a user-selected constant multiplied by an equation published by Sharpley (1980), that is similar to that used in the CREAMS model (Menzel 1980) (Equation 5). The enrichment ratio decreases as the daily sediment amount $(\mathrm{kg} / \mathrm{ha})$ increases.

$\ln ($ enrichment ratio $)=$ InputConstant $*(2.4-0.27 * \ln ($ sed $))$

where sed is the daily sediment discharge $(\mathrm{kg} / \mathrm{ha})$, and $\ln ()$ indicates the natural logarithm.

Method (i) is simple, and is especially suitable if the ratio has been measured (Sharpley 2007). In general, soils with sandy or organic surface layers or P stratified in the surface are likely to have higher enrichment ratios than clay soils and uniform soils. Method (ii) is based on data from soils in Queensland that ranged from 26 to $65 \%$ clay, and so is best suited to clay soils. The enrichment ratios are high (5.1) for soils less than $30 \%$ clay. This method is based on limited data. Method (iii) is based on large datasets, and describes the common situation where increasing daily rates of erosion decrease enrichment. This may be due to greater export of coarse material relative to fines in high energy events, or the depletion over time of concentrated sources of $\mathrm{P}$. The dataset used to fit this function included many loam and light clay soils (with InputConstant=1). InputConstant was added to the function to allow for situations where the minimum enrichment ratio is greater than 1. If the constant is unknown it can usually be assumed to be 1 for highly aggregated, structured soils (e.g. Vertosols) to 2 for un-aggregated, structureless soils (e.g. Kandosols).

The model was tested using data collected over 6 years $(2000-2005)$ from a cropped catchment at the Brigalow Catchment Study (C2, Cowie et al. 2007). Soil descriptions and measurements, cropping history, weather observations and other input data were available. Table 2 shows key soil parameters used to represent the mix of Vertosols and Dermosols (Isbell 1996) at the site. Available validation data included many measurements of crop and residue cover, runoff, and a few measurements of dissolved and sediment $\mathrm{P}$ concentrations.

Table 2. Key parameters for the soil at the Brigalow Catchment Study.

\begin{tabular}{|c|c|c|c|c|c|}
\hline & Layer 1 & Layer 2 & Layer 3 & Layer 4 & Layer 5 \\
\hline Depth of bottom of layer (mm) & 100 & 200 & 400 & 1000 & 1500 \\
\hline Lower limit of plant extraction (\% volumetric) & 15 & 19 & 19 & 19 & 26 \\
\hline Drained upper limit (\% volumetric) & 33 & 36 & 36 & 32 & 31 \\
\hline Saturation (\% volumetric) & 52 & 43 & 43 & 36 & 37 \\
\hline Maximum drainage ( $\mathrm{mm} /$ day) & 100 & 10 & 5 & 2 & 1 \\
\hline Bulk density $\left(\mathrm{g} \mathrm{cm}^{-3}\right)$ & 1.2 & 1.2 & 1.6 & 1.7 & 1.6 \\
\hline
\end{tabular}


Other soil parameters used in the simulation include: Runoff curve number $(\mathrm{CN})=78, \mathrm{CN}$ reduction at $100 \%$ cover $=8, \mathrm{CN}$ reduction for tillage $=5$, field slope $=1.2 \%$, slope length $=100 \mathrm{~m}$, USLE K $=0.4$ (metric units), soil evaporation $U=8 \mathrm{~mm} /$ day, soil evaporation Cona $4 \mathrm{~mm} /$ day $^{0.5}$, USLE rill:interrill ratio $=0.4$.

\section{RESULTS AND DISCUSSION}

These simulations used method (i) for DRP (Howleaky? function II), and method (ii) for particulate P (ie the modified Creams enrichment function) with an input coefficient of 2 . Accurate prediction of runoff is a prerequisite to the accurate prediction of $\mathrm{P}$ export in runoff. Figure 2 shows that daily runoff was accurately predicted for most events $\left(\mathrm{R}^{2}=0.77\right.$ ). The RMSE of daily runoff estimates was $8.2 \mathrm{~mm}$ (of data where the modelled or measured values were non-zero). This was despite poor accuracy in the simulation of ground cover (Figure 3).

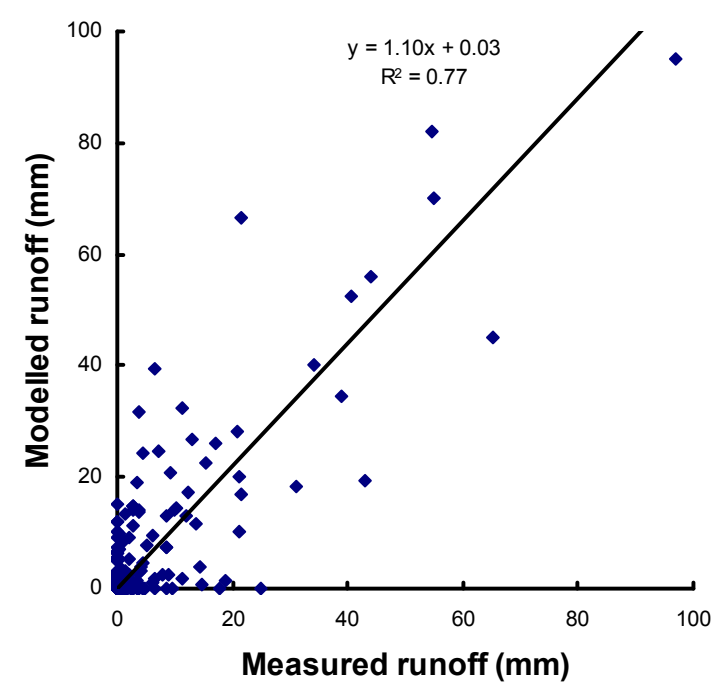

Figure 2. Measured and modelled runoff at the Brigalow Catchment Study.

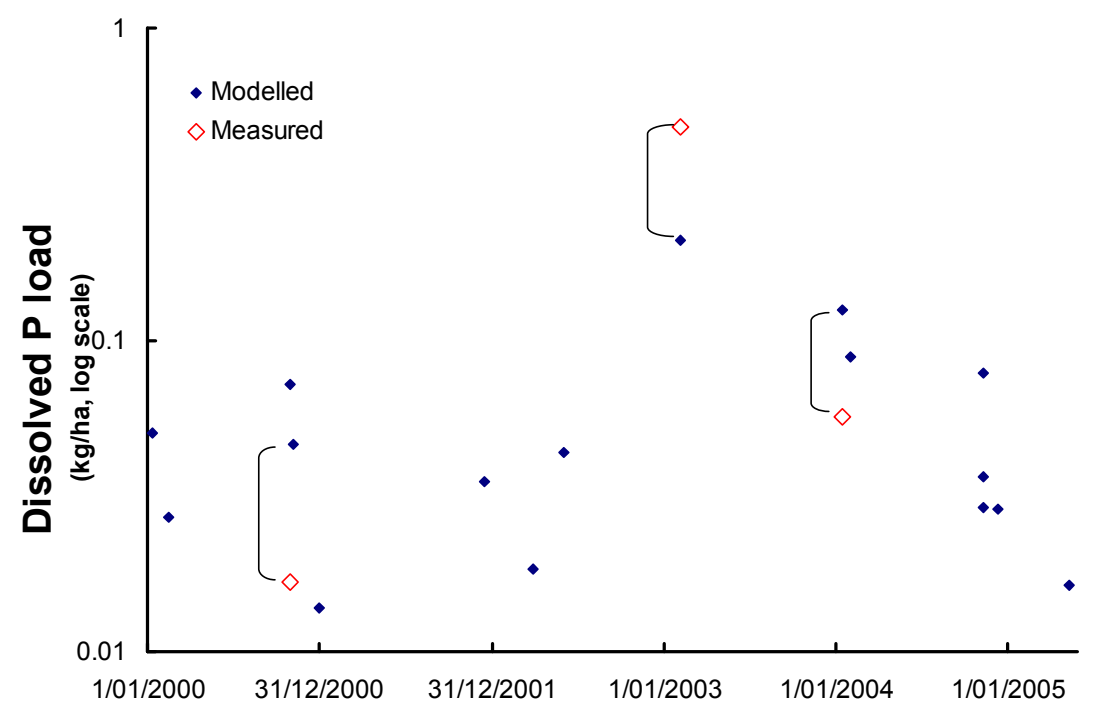

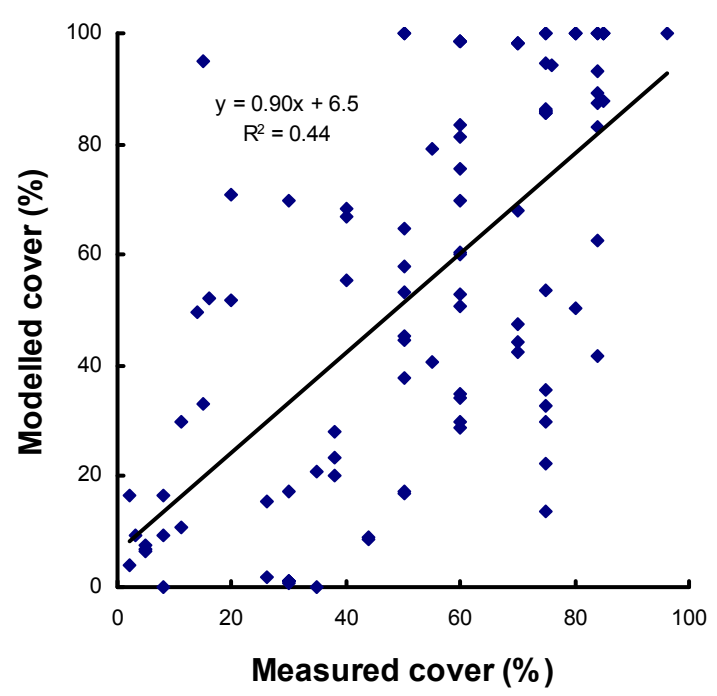

Figure 3. Measured and modelled ground cover at the Brigalow Catchment Study.

Figure 4. Modelled and measured loads of dissolved $P$ at the Brigalow Catchment Study. For the three measurements, the modelled data are linked by a "[". 
Daily exports of $\mathrm{P}(\mathrm{kg} / \mathrm{ha} /$ day), as dissolved $\mathrm{P}$ or as $\mathrm{P}$ in suspended particles, are shown in Figures 4 and 5 , respectively. Each point is the product of the respective $\mathrm{P}$ concentrations $(\mathrm{mg} \mathrm{P} / \mathrm{L})$ and runoff amounts (ML/ha/day). These figures show that the measured data, though scant, are spread across the range of modelled values. The differences between measured and predicted values were less than expected.

The total of the measured and modelled DRP from the Brigalow Catchment Study from January 2000 to December 2004 were 0.56 and $0.44 \mathrm{~kg} / \mathrm{ha}$, respectively. For particulate $\mathrm{P}$ the values are 0.45 and $0.61 \mathrm{~kg} \mathrm{P} / \mathrm{ha}$ for the model and measured, respectively. Given the considerable magnitude of possible errors in such a simulation, we were pleased with the agreement between the measured and modelled values.

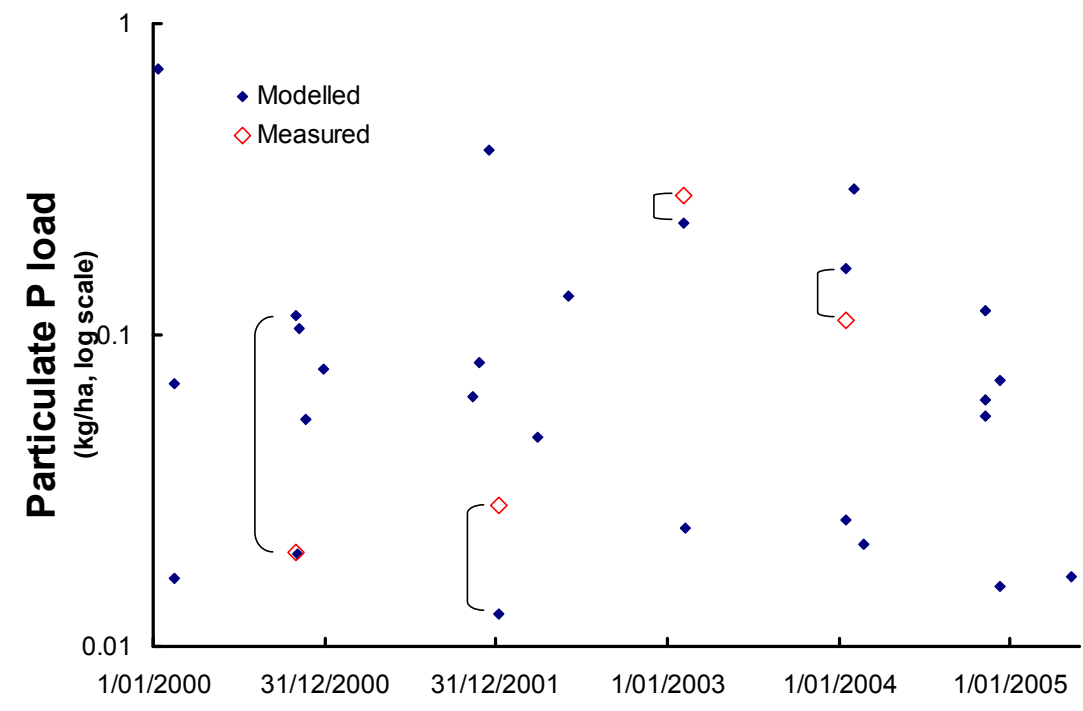

Figure 5. Modelled and measured loads of particulate $P$ at the Brigalow Catchment Study. For the 4 measurements, the modelled data are linked by a "[".

\section{CONCLUSIONS}

Good agreement has been found between predictions by the new model and measured data for P export in runoff from a field site.

\section{ACKNOWLEDGMENTS}

The authors are thankful to colleagues who have anonymously reviewed the manuscript and offered helpful feedback.

\section{REFER ENCES}

Burkitt, L.L., Moody, P.W., Gourley, C.J.P., and Hannah, M.C. (2002). A simple phosphorus buffering index for Australian soils. Australian Journal of Soil Research, 40, 497-513.

Colwell, J.D. (1963). The estimation of the phosphorus fertilisers requirements of wheat in southern New South Wales by soil analysis. Australian Journal of Experimental Agriculture and Animal Husbandry 3, 100-107.

Cowie, B.A., Thornton, C.M. and Radford, B.J. (2007). The Brigalow Catchment Study: I. Overview of a 40year study of the effects of land clearing in the brigalow bioregion of Australia. Australian Journal of Soil Research, 45, 479-495.

Dougherty, W., Burkitt, L., Milham, P., and Harvey, D. (2010). The effect of soil available P and P buffering on runoff $\mathrm{P}$ concentration from pastures. 19th World Congress of Soil Science, Soil Solutions for a Changing World, 1 - 6 August 2010, Brisbane, Australia.

Haith, D.A., and Shoemaker, L.L. (1987). Generalised watershed loading functions for stream flow nutrients. Water Resources Bulletin, 23, 471-478.

Herath, G. (1997). Freshwater algal blooms and their control: Comparison of the European and Australian experience. Journal of Environmental Management, 51, 217-227.

Isbell, R.F. (1996). The Australian soil classification. CSIRO Publishing, Melbourne. 
Langmuir, I. (1916). The constitution and fundamental properties of solids and liquids. Part 1: solids. Journal of the American Chemistry Society 38, 2221-95.

Littleboy, M., Freebairn, D.M., Silburn, D.M., Woodruff, D.R. and Hammer, G.L. (1999). PERFECT Version 3.0. A computer simulation model of productivity erosion runoff functions to evaluate conservation techniques, available at http:/www.apsru.gov.au/apsru/Products/Perfect/PERFECT.HTM

Menzel, R.G. (1980). Enrichment ratios for water quality modeling. In: W.G. Knisel (Editor). CREAMS--A field-scale model for Chemicals, Runoff, and Erosion from Agricultural Management Systems. U.S. Department of Agriculture, Conservation Research Report, No. 26, pp. 486-492.

Ozanne, P.G., and Shaw, T.C. (1968). Advantages of the recently developed phosphate sorption test over older extractant methods for soil phosphate. In: Transactions of the 9th International Congress in Soil Science. Adelaide. Vol . 2, 273-280. International Society of Soil Science

Rattray, D.J., Freebairn, D.M., McClymont, D., Silburn, D.M., Owens, J. and Robinson, J.B. (2004). HOWLEAKY? - the journey to demystifying simple technology, paper presented at Conserving Soil and Water for Society: Sharing Solutions, the 13th International Soil Conservation Organisation Conference. Brisbane, July 2004.

Robinson, J.B., Rattray, D., Freebairn, D., Silburn, D.M., and McClymont, D. 2007. Linking land management to nutrient concentrations and loads using a simple hydrologic model. MODSIM 2007 International Congress on Modelling and Simulation. Modelling and Simulation Society of Australia and New Zealand. Christchurch, NZ.

Sharpley, A.N. (1980). The enrichment of soil phosphorus in runoff sediments. Journal of Environmental Quality, 9: 521-526.

Sharpley, A. N. (1995). Dependence of runoff phosphorus on extractable soil phosphorus. Journal of Environmental Quality 24, 920-926.

Sharpley, A. N. (2007). Modeling phosphorus movement from agriculture to surface waters. In: D.E. Radcliffe and M.L. Cabrera, Modeling phosphorus in the environment. CRC Press, Boca Raton, FL.

Sharpley, A.N., Smith, S.J., Jones, O.R., Berg, W.A. and Coleman, G.A. (1992). The transport of bioavailable phosphorous in agricultural runoff. Journal of Environmental Quality, 21, 30-35.

Sharpley, A.N., Chapra, S.C., Wedepohl, R., Sims, J.T., Daniel, T.C. and Reddy, K.R. (1994) Managing agricultural phosphorus for protection of surface waters: Issues and options. Journal of Environmental Quality 23, 437-451.

Silburn, D.M., Robinson, J.B. and Freebairn, D.M. (2007). Why restore marginal cropland to permanent pasture? - land resource and environmental issues, Tropical Grasslands, 41, 139-153.

Vadas, P.A., Kleinman, P.J.A., Sharpley, A.N. and Turner, B.L. (2005). Relating soil phosphorus to dissolved phosphorus in runoff: A single extraction coefficient for water quality modeling. Journal of Environmental Quality 34, 572-580.

Wolfe, M.L. (2007). Modeling runoff and erosion in phosphorus models. In: D.E. Radcliffe and M.L. Cabrera, Modeling phosphorus in the environment. CRC Press, Boca Raton, FL. 